\title{
IMPACTS AND POTENTIAL OF AUTONOMOUS VEHICLES IN TOURISM
}

\author{
Márk MISKOLCZIa ${ }^{a}$,ászló KÖKÉNY ${ }^{b}$, Katalin ÁSVÁNYIc, \\ Melinda JÁSZBERÉNYI ${ }^{d}$, Tamás GYULAVÁRI ${ }^{\mathrm{e}}$, Jhanghiz SYAHRIVAR ${ }^{\mathrm{f}}$
}

\footnotetext{
${ }^{a}$ Corvinus University of Budapest, Institute of Marketing, mark.miskolczi@uni-corvinus.hu

${ }^{\mathrm{b}}$ Corvinus University of Budapest, Institute of Marketing, laszlo.kokeny2@uni-corvinus.hu

${ }^{c}$ Corvinus University of Budapest, Institute of Marketing, katalin.asvanyi@uni-corvinus.hu

${ }^{\mathrm{d}}$ Corvinus University of Budapest, Institute of Marketing, jaszberenyi@uni-corvinus.hu

e Corvinus University of Budapest, Institute of Marketing, tamas.gyulavari@uni-corvinus.hu

${ }^{\mathrm{f}}$ Corvinus University of Budapest, Institute of Marketing, jhanghiz@uni-corvinus.hu
}

Cite this article: Miskolczi, M., Kökény, L., Ásványi, K., Jászberényi, M., Gyulavári, T., Syahrivar, J. (2021). Impacts and potential of autonomous vehicles in tourism. Deturope, 13(2): 34-51.

\begin{abstract}
Autonomous vehicles (AVs) are developing rapidly, but the deeper understanding of tourists' attitudes towards AVs is still little explored in social sciences. Bearing this in mind, this study aims to identify the expected changes in tourism arising from the technology, and the openness towards AV-based tourism services. For this, an online data collection $(n=671)$ has been completed among Hungarian tourists. Prior to the data collection, a literature review was conducted to identify and categorise the changes expected from the spread of AVs. Based on the empirical results, tourists would be willing to give up control to the AVs in a foreign environment, and so to pay more attention to the surroundings. The majority of respondents would be also open to participating in AI-based city tours, especially those with the "Extraversion" and "Openness to Experiences" personality types, based on the Big Five Theory. The findings can serve as a basis for practitioners in preparing for the technology and for the further analysis of attitudes towards tourism-based AV services (e.g., modeling of technology acceptance).
\end{abstract}

Keywords: autonomous vehicles (AVs), tourism service development, attitudes towards autonomous vehicles, tourism consumer behavior

\section{INTRODUCTION}

Nowadays, one of the biggest issues of passenger transport is to find a balance between economic sustainability, environmental regulations, and even travelers' satisfaction (Tromaras et al., 2018; Bagloee et al., 2016). Automation is one of the promising technologies of Industry 4.0 that can transform many industries, including tourism and passenger transport (Fagnant \& Kockelman, 2015). According to optimistic (pre-pandemic) estimates, 27 million AVs are expected to be on the roads by 2030 in Europe, and 40\% of passenger kilometers will be performed by AVs (PWC, 2018). Despite this radical improvement, there are several unanswered questions (legal - e.g., Glancy, 2015; moral and sectorial - e.g., Miskolczi et al., 
2021, De Sio, 2017; social - Bissell et al., 2020) around the technology. Most of the literature on AVs consider primarily the technical feasibility (Run \& Xiao, 2018; Zhao et al., 2018) as well as the general advantages and disadvantages of spread (Nielsen \& Haustein, 2018; Du \& Zheng, 2021).

In our study, we especially concentrate on the attitudes towards the use of AV for tourism purposes. Our research aims to reveal how tourists with different consumer habits relate to AVbased tourism services that we have identified in the literature. In our empirical research, the correlation between the subjects' personality type and attitude towards AVs has also been analyzed. There are only a few papers (e.g., Tussyadiah \& Zach \& Wang, 2017; Cohen \& Hopkins, 2019) that analyze the impact of AVs on tourism which reinforces the relevance of our research objective. Findings revealed a generally positive attitude towards AV-based tourism services. According to respondents' assumptions, AVs would improve the tourism experience, as their use would allow for a more convenient way of visiting the destination and its attractions.

Our study is structured as follows: In Section 2, the basic definitions of AV technology and the results of previous research related to our research topic are discussed. The process and results of empirical research (Section 3) are interpreted along with three main topics (Section 4): tourism habits of subjects, attitudes towards AV-based tourism services, and the correlation between personality types and openness to the AV technology. In Section 5, we answer our research questions and make suggestions for the application of AVs in tourism.

\section{THEORETICAL BACKGROUND}

A significant part of transport is realized due to tourism motivations. Therefore, such disruptive innovations like automation in passenger transport might also affect tourism (Jászberényi \& Munkácsy, 2018). Nowadays, the main objective of transport development initiatives is to reduce the number of accidents caused by human error, which currently accounts for $90 \%$ of road accidents (Menezes et al., 2017). Automation determines the replacement of processes by machines that previously required human intervention (Fagnant \& Kockelman, 2015; Nikitas et al., 2017). 
Automation is an incremental innovation in transport. To define the nature of this phenomena, the $\mathrm{SAE}^{1}$ (Society of Automotive) framework developed by the National Highway Traffic Safety Administration $\left(\mathrm{NHTSA}^{2}\right)$ should be interpreted, which is structured as follows:

- Level 0: "No Automation": Conventional way of using a vehicle without any automation.

- Level 1: "Driver Assistance": Only the human driver controls the vehicle, but there are some supporting functions (e.g., cruise control).

- Level 2: "Partial Automation": The human driver controls the vehicle, but advanced driving assistance systems (ADAS) (e.g., lane-centering, IPAS ${ }^{3}$ ) are available.

- Level 3: "Conditional Automation": The human driver is still responsible for controlling the vehicle, but the continuous monitoring of the environment is no longer required; artificial intelligence (AI) performs all driving operations. On the other hand, in the case of special traffic situations, human drivers must take back control over the machine. Currently, the most advanced vehicles achieve this level of automation (Honda company's new development - Sensing Elite Traffic Jam Pilot ${ }^{4}$ ).

- Level 4: "High Automation": The vehicle manages all driving functions and controls itself under certain conditions (e.g., adequate $5 \mathrm{G}$ coverage of the operating zone).

- Level 5: "Full Automation": The vehicle possesses and maintains all driving functions completely (without zone restrictions).

\section{GENERAL FORECASTS AND SOCIO-ECONOMIC IMPACTS OF AUTOMATION}

The impacts of AVs from different aspects have been addressed by several researchers in recent years. Researchers primarily examine how the spread of AVs changes the mobility patterns and space utilization in urban environment (Bagloee et al., 2016; Madigan et al., 2017; Tokody \& Mezey, 2017), the role of car use in the future of passenger transport (Zmud et al., 2013; Arbib \& Seba, 2017; Lagadic, Verloes, \& Louvet, 2019) and the travel experience (Prisecaru, 2016; Clements \& Kockelman, 2017; Marletto, 2019; Syahrivar et al., 2021).

\footnotetext{
${ }^{1} \mathrm{https}: / /$ www.sae.org/news/press-room/2018/12/sae-international-releases-updated-visual-chart-for-its- $\% \mathrm{E} 2 \% 80$ $\% 9$ Clevels-of-driving-automation $\% \mathrm{E} 2 \% 80 \% 9 \mathrm{D}$-standard-for-self-driving-vehicles

2 https://www.nhtsa.gov/

${ }^{3}$ Intelligent Parking Assist System.

${ }^{4} \mathrm{https}$ ://hondanews.com/en-US/honda-corporate/releases/release-e86048ba0d6e80b260e72d443f0e4d47-hondalaunches-next-generation-honda-sensing-elite-safety-system-with-level-3-automated-driving-features-in-japan
} 


\section{Altering mobility patterns}

As technology evolves, travellers' mobility habits could change significantly. Studies addressed some remarkable benefits of automation like the increased usefulness of travel time (e.g., decreasing traveling time and widening of activities during mobility - Kyriakidis et al., 2015; Platt, 2017) and the environmental and economic benefits of automation (e.g., less energy consumption, lower travel costs - Bagloee, 2016). Research on urban and transport development (Freudendal-Pedersen et al., 2019; Schipper, 2020) emphasizes that, with the widespread use of AVs, urban traffic flows could improve, fewer parking spaces will be needed, thus reducing the environmental impact of the sector.

Research also suggests that the emergence of AVs may also widen the range of people who were previously unable to travel alone (e.g., without a driving licence, due to health problems, etc.). Sivak and Schoettle (2015) surveyed 1,500 people in the UK, Australia, and the United States. The most important findings are that $60 \%$ of the people involved in the research had a positive attitude towards technology (high willingness to try AVs). Platt's (2017) research in Canada examined different aspects of AVs. Results proved that frequent travelers are more receptive and families with young children are the most distrustful (they consider it too risky to hand over the driving tasks to the machine). The analysis of the general impacts, such as socioeconomic externalities (e.g., altering of consumer preferences, labor market reorganization), are currently the most important and unanswered issues around the technology.

\section{Altering car usage and perception of the machine}

Research on travel psychology and behavior suggest that driving a car represents the dominance of the person in a certain micro-community (e.g., family, friends) and enhances confidence (Urry, 2004). In contrast, at the level of full automation, these psychological benefits (e.g., driving experience, enjoying gear shifting, control the vehicle, etc.) might disappear. At SAE level 4-5, there will be no need for a driver's license, which could also weaken the prestige of automobiles. Research highlights that constantly evolving automation makes car use simpler and more comfortable, which can guide travelers to this means of transport, i.e., the importance of other environment-conscious modes (e.g., public transport) might be decreased in the long run (Currie, 2018). One of the most important issues regarding AVs is road safety and data security. Although increased road safety is one of the major benefits of automation, research has shown (Xu et al., 2018; Liljamo et al., 2018) that there is noteworthy mistrust in fully 
automated vehicles, primarily due to uncertainty and the lack of in-depth knowledge about the machine.

\section{Altering travel experience}

Another significant influencing factor can be the novelty of the driving experience. Pitcher (2011) highlights that the usage of AVs seems to be easy to learn, easy to operate, and does not require meaningful efforts. Other research stresses the negative impacts of self-driving cars on driver experience. It has been revealed that individuals who seek complex and intense sensory experiences, tend to drive at a higher average speed (Becker \& Axhausen, 2017) and keep shorter tracking distance (Payre et al., 2014). Obviously, this cannot be provided by the usage of self-driving cars; the human driver becomes a passive observer at higher levels of automation (SAE Level 4-5). Individuals who are stick to intense driving experiences would be less likely to prefer a complete handover of driver's responsibilities, as this would reduce the intense sensory experience they require (Gardner \& Abraham, 2007). It is also worth pointing out that a self-driving car may enhance the sense of freedom by serving special mobility needs as a "moving living room, or office" and new activities on board.

Table 1. General issues regarding autonomous vehicles (SAE Level 4-5)
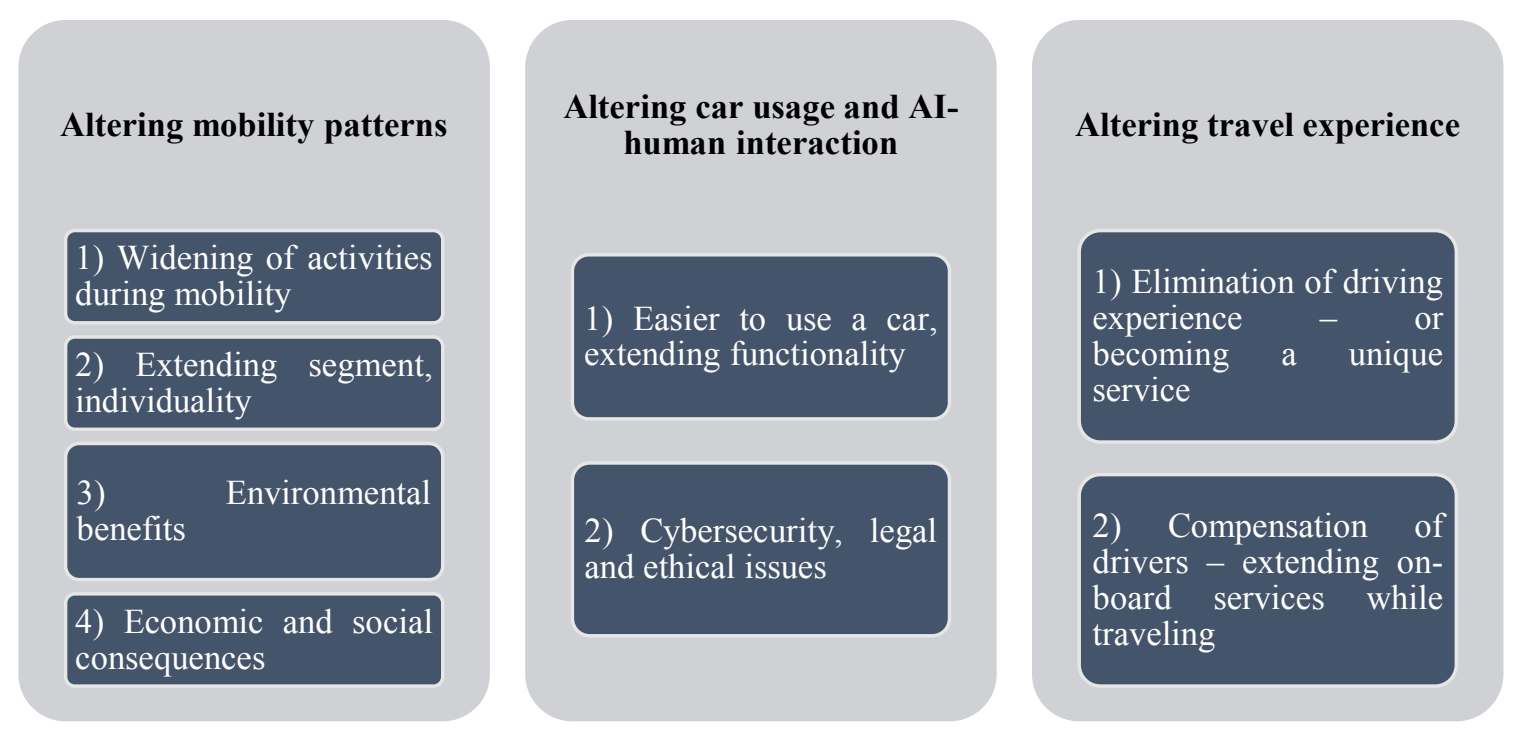

Source: Authors' own editing based on the literature review

\section{Impacts of AVs on tourism services}

Although previous research analysing the impacts of AVs in tourism is limited, several possible consequences can be identified. During the transition period (on a lower level of automation SAE Level 2-3), mobility opportunities may change (e.g., easier approaching of a more distant 
destination with a car equipped with ADAS), but more radical tourism-related alterations can be predicted on the full level of automation. Based on this, we focus on exploring the potential effects of SAE level 4-5 automation.

The possible changes in the field of tourism are interpreted along with three main topics: tourism alterations that can be associated with the handover of driving tasks, the increasing accessibility, and the new (possible) applications of vehicles for tourism purposes.

\section{Handover of driving tasks during tourism-related travel}

At the level of full automation, the lack of the need for a driver's license poses barriers for travellers who, due to their age or health constraints, would not be able to travel alone for tourism (Anderson et al., 2014). This consumer group becomes more independent and flexible in their mobility and could reduce their social isolation (IFMO, 2016; Koul \& Eydgahi, 2018). Based on forecasts, the spread of AVs could increase travel demand by about $11 \%$ in the next decade (Sivak \& Schoettle, 2015). Research also emphasize (Cohen \& Hopkins, 2019) that passengers can embark on new activities while traveling (e.g., relaxation, admiring the environment) instead of driving. Decreasing travel time can also change travel mode preferences, making AVs more attractive than other modes of transport, such as rail transport or aviation. Door-to-door mobility can also reduce travel time compared to public transport, which may lead to a reduction in the use of public transport (IFMO, 2016). The use of AVs also offers an additional option for people who have a driving licence but are reluctant to drive to a foreign destination. When sitting in an $\mathrm{AV}$, it is not necessary to be aware of the driving rules of the destination (e.g., left- and right-hand traffic), thus, the unknown environment will no longer be a limiting factor (Cohen \& Hopkins, 2019).

\section{Increasing accessibility of destinations and attractions}

As a result of the optimized traffic realized by AVs, travel speed increases and travel time decreases, allowing tourists to travel longer distances in the same time interval (Bagloee et al., 2016). Due to the constant travel speed, route and travel time planning is more reliable and predictable (Kim et al., 2015). Tourists will also be able to reach more distant and previously little-visited attractions, giving AVs the opportunity to reach new destinations and attractions (Cohen \& Hopkins, 2019). In the light of the expected changes, AVs can replace the role of conventional shuttle buses and taxi services, thus, completely repositioning the importance of the means of passenger transport (Bainbridge, 2018). 


\section{New (possible) applications of AVs for tourism purposes}

With the spread of automation, new AV-based services might also emerge in tourism. There may be a need for using conventional vehicles (human-driven) if this is no longer possible in the destination visited. On the other hand, testing self-driving cars on SAE Level 4-5 in places where technology is not yet widespread can also appear as travel motivation (Ásványi et al., 2020). With the application of AVs, a new way of sightseeing (AutoTour) could be created (Bainbridge, 2018). This would work on a similar principle to hop on - hop off bus tours in cities but could also replace walking tours. AutoTour services might be more flexible since the route can be easily configured in real-time, along with tourists' preferences. At the same time, the service raises sustainability issues. Tourism habits, the behavior of tourists might be radically changed due to the emergence of AVs. Tourists - who were previously responsible for driving and monitoring the environment - can drink alcohol since they are released from the obligations. Evening tours and parties might become more attractive in urban spaces and decrease the responsible attitude of visitors (Bainbridge, 2018). In the early stages of diffusion, there may also be an increasing demand for test (experience) "driving" of $A V s$. Since the interior design of AVs can be modified, vehicles can offer new (tourism-related) services that might affect $\mathrm{MICE}^{5}$ tourism, hospitality, and hotel industry. Passengers in specially designed AVs can sleep while travelling, so passengers may not need to book accommodation as they might not have to stop for a rest during a long-distance trip (Cohen \& Hopkins, 2019).

Table 2 Impacts of AVs on tourism
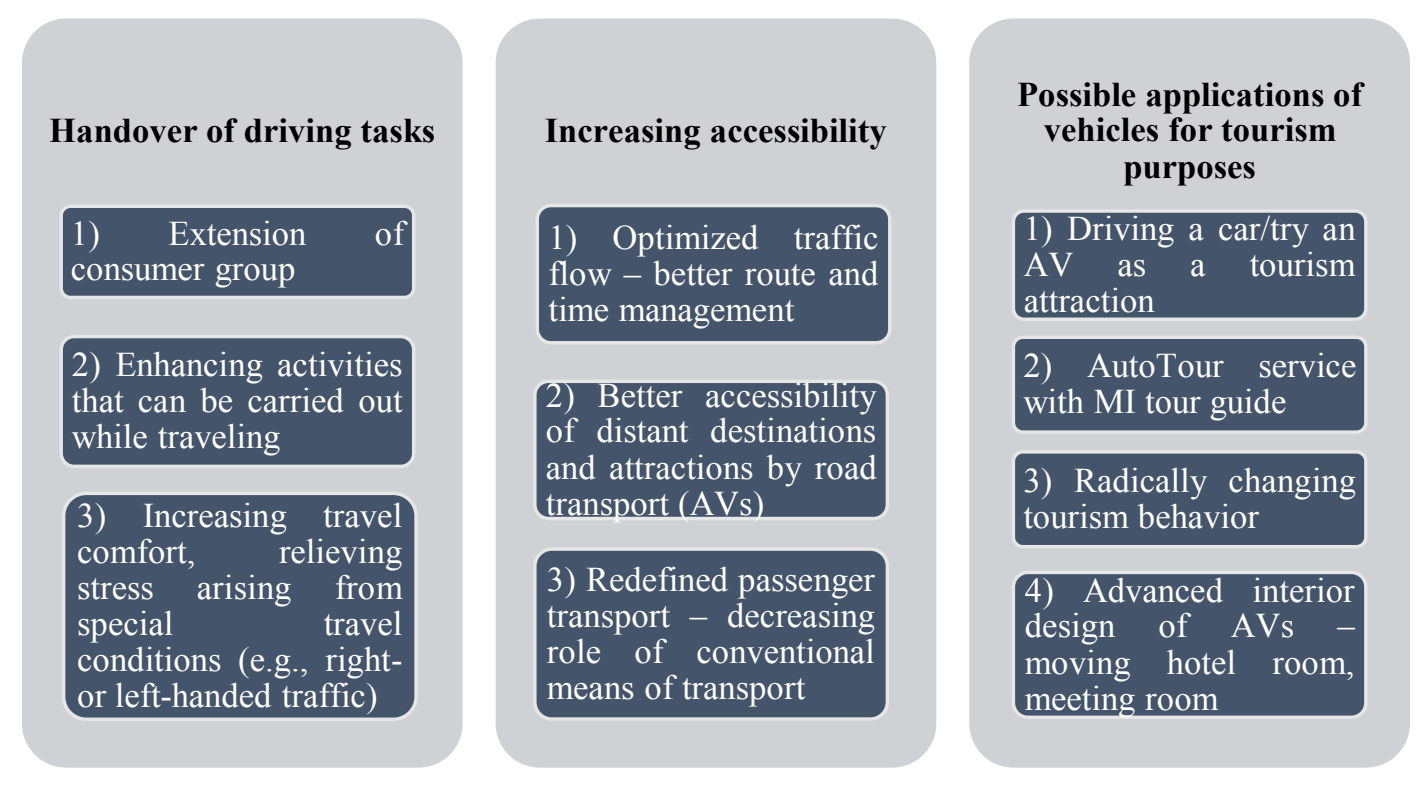

Source: Authors' own editing based on the literature review.

\footnotetext{
${ }^{5}$ The umbrella term for business tourism: Meetings, Incentives, Conferences \& Exhibitions.
} 


\section{Research gaps identified by the literature review}

Based on the literature review, the following key findings and research gaps have been identified that determine the empirical phase of our research. The literature on the diffusion of AVs is extensive, based on which we have synthesized the general impacts into three main categories: Altering mobility patterns (1), Altering car usage and perception of the machine (2), and Altering travel experience (3). Nevertheless, sector-specific analyses are limited, especially the literature on tourism impacts. Based on the journal articles identified, a new framework of expected tourism impacts has been developed (see Table 2). No empirical research on the impact of self-driving cars on tourism has been found, nor did any other research consider factors other than traditional sociodemographic variables. This confirmed the relevance of our study and the application of the Big Five Personality Trait to extend the segmentation of tourists who are open to using AVs.

In the light of these, the empirical research investigates attitudes towards possible tourismrelated AV applications identified in the literature: namely, the willingness to hand over the driving tasks in foreign environment to better observe the surrounding, the openness to use AVS for sightseeing, the intention to use AI-based tour guiding (AutoTour service), AVs for experience driving, and the openness to do new activities while travelling (instead of driving relaxation, conduct meetings, etc.).

\section{DATA AND METHODS}

Data collection has been carried out online, between October-December 2020, and resulted in 671 responses. The number of subjects involved in the survey exceeds the expected size of exploratory marketing research (Malhotra, 2009) and so the outcomes can be approved and utilized for further analysis.

Based on the literature review, we have formulated three research questions (RQs):

- RQ1: How do tourists relate to the use of AVs at the level of full automation?

- RQ2: Which of the AV-based tourism services identified in the literature are attractive among tourists?

- RQ3: What personality types are open to AV-based tourism services?

Respondents from Hungary who regularly takes part in trips for tourism purposes were included in the analysis. Respondents had to associate with the pre-COVID19 period during the completion of the survey. 
With our questions, the tourism and mobility habits, the personality type of the subjects based on the Big Five Personality Traits (Table 3) framework have been identified. The Big Five is one of the most important personality models in psychology, according to which subjects can be classified into five factor groups (Cobb-Clark \& Schurer, 2012).

Extraversion (1) involves the free expression of impulses, and subjects in this category are characterized by assertiveness and dominance in social behaviour (Cobb-Clark \& Schurer, 2012). The Conscientiousness (2) group includes those who are organized, selfdisciplined and duty conscious. Agreeableness (3) is usually referred to as the ability to maintain relationships. Subjects of this category have high empathy and trust.

People in the Neuroticism (4) category are prone to unrealistic thinking, and less able to control their impulses (Komarraju et al., 2011). Based on this, they might experience a lot of stress, are anxious and more vulnerable. Subjects of the last category, the Openness to Experience (5) are characterised by creativity, out of box thinking, and openness to new ideas (De Raad, 2000).

Table 3. Main characteristics of Big Five Personalities based on Gosling et al. (2003) and Komarraju et al. (2011)

\begin{tabular}{|l|l|}
\hline Category & Main characteristics \\
\hline Extraversion & sociable, energized by social interactions, outgoing \\
\hline Conscientiousness & organized, self-disciplined, duty conscious \\
\hline Agreeableness & high empathy, altruist, high trust \\
\hline Neuroticism & experience a lot of stress, anxious, vulnerable \\
\hline Openness to Experience & curious, creative, out of the box behaviour \\
\hline
\end{tabular}

Source: Authors' own editing.

A Likert scale ranging from 1 to 7 has been applied to explore attitudes towards AVbased tourism services. During the analysis, mean values above 4 were considered positive (i.e., represents openness to tourism-based services). In addition to the basic descriptive statistics (e.g., mean, standard deviation, mode, median), the Kruskal-Wallis test has been employed to identify significant differences among variables. The strength of the test was assessed based on Eta-squared test suggested by Tomczak and Tomczak (2014). 


\section{RESULTS}

\section{Sociodemographic characteristics of the sample}

By gender, the sample is relatively balanced: of the 671 people surveyed, $56.3 \%$ are women and $43.3 \%$ are men. The sample consists of subjects of all age groups. The largest proportion $(27 \%)$ is in the $18-29$ age group, followed by the over-60 age group (25\%). The $30-39$ age group has a slightly lower proportion (21\%), while the $40-49$ age group is represented by $15 \%$ and the $50-59$ age group by $12 \%$. Most of the respondents live in the capital (40.2\%) of Hungary, $29.4 \%$ in other cities, $17.4 \%$ in county seats, and $12.7 \%$ in villages.

\section{Tourism-related consumer and mobility habits}

Subjects' tourism-related consumer habits have been analyzed in terms of travel frequency (1), way of organizing travel (individual travel or package tour) (2), travel motivations (most preferred tourism product) (3) and means of transport used to travel to (4) and from the destination (5).

1 Based on the results, $6.5 \%$ of the total sample make several trips a month or more per year. $27.6-27.6 \%$ of respondents travel for tourism purposes every six months or every year. In addition, a further $24.8 \%$ travel every few months.

2 Majority of respondents $(80.2 \%$ of the total sample) organize their trips individually; package tours are not common among subjects.

3 In terms of motivation, the most popular tourism activities are recreation (26\%), urban and cultural tourism (17\%), wellness (15\%) and $\mathrm{VFR}^{6}$ (visiting friends and relatives) $(13 \%)$. The share of other tourism products (e.g., MICE, active tourism, festival tourism, niche elements) is below $10 \%$.

4 Majority of tourists use their cars (68.2\%), but airplanes (44.2\%), trains (32.8\%), and buses $(27.7 \%)$ are also common ways to reach the destinations. A negligible proportion of tourists rent a car $(6.2 \%)$ or use carpooling services $(1.7 \%)$.

5 At the destination, the vast majority of subjects travel by car (64.9\%), use public transport $(50.9 \%)$ or approach attractions on foot $(53.8 \%)$. Relatively few people rent a car $(17.4 \%)$ or decide to use shared mobility services (e.g., carsharing) (2.3\%), or micro-mobility vehicles $(2.9 \%)$.

\footnotetext{
${ }^{6}$ Visiting Friends and Relatives.
} 


\section{Attitudes towards tourism alterations based on AV use}

Based on the attitudes towards AV-based tourism services, the following findings have been revealed:

Respondents were asked how much they would prefer to use self-driving cars to pay attention to the environment rather than driving. Based on the responses, there is a high openness towards AVs in this context (Mean: 4.45; Median: 5). Tourists also stated that they would be willing to give up control to the machine in a foreign environment (Mean: 4.52, Median: 6). However, there is also a sense of caution among tourists, as they are less open to leisure activities (e.g., sleeping, reading, etc.) while traveling in an AV (Mean: 3.55, Median: $3)$.

When asked whether tourists would use AVs for sightseeing, there was also a high proportion of positive responses (Mean: 4.51, Median: 5). The willingness to visit more distant destinations and to use AVs in a foreign environment also scores above 4.

Tourists would be open to a tourist service in which the machine (AI) would be the tour guide (AutoTour) (Mean: 4.64, Median: 5). The openness towards experience driving with AVs responses are particularly positive (Mean: 4.77, Median: 5).

The intention to use extended AV-based services (e.g., mobile meeting room - Mean: 4.21, Median: 5; interior for sleeping - Mean: 4.05, Median: 4) is slightly lower but above 4. Standard deviation values are below 2 in every cases. The most frequent element in every case is 5, which also indicates a high degree of openness.

Table 4 Correlation between travel frequency and possible application of AVs for tourism purposes

\begin{tabular}{|c|c|c|c|c|c|c|c|}
\hline Item & $\begin{array}{l}\text { Monthly } \\
\text { or often }\end{array}$ & $\begin{array}{c}\text { A few times } \\
\text { a year }\end{array}$ & $\begin{array}{l}\text { Twice } \\
\text { a year }\end{array}$ & Annually & $\begin{array}{c}\text { Less } \\
\text { frequently }\end{array}$ & H statistics & Eta $^{2}$ \\
\hline $\begin{array}{l}\text { Openness to do } \\
\text { sightseeing conducted by } \\
\text { an AI-based tour guide } \\
\text { (AutoTour). }\end{array}$ & $\begin{array}{c}4.73 \\
(1.84)\end{array}$ & $\begin{array}{c}4.83 \\
(1.81)\end{array}$ & $\begin{array}{c}4.49 \\
(1.82)\end{array}$ & $\begin{array}{c}4.57 \\
(1.86)\end{array}$ & $\begin{array}{c}3.55 \\
(1.90)\end{array}$ & $22.787 * * *$ & 0.03 \\
\hline $\begin{array}{l}\text { Openness to use Avs that } \\
\text { are suitable to conduct } \\
\text { meetings. }\end{array}$ & $\begin{array}{c}4.21 \\
(1.85)\end{array}$ & $\begin{array}{c}3.69 \\
(1.91)\end{array}$ & $\begin{array}{c}3.42 \\
(1.86)\end{array}$ & $\begin{array}{c}3.44 \\
(1.94)\end{array}$ & $\begin{array}{c}3.06 \\
(1.85)\end{array}$ & $16.429 * *$ & 0.02 \\
\hline $\begin{array}{l}\text { Openness to use AVs } \\
\text { which have an interior } \\
\text { design for sleeping. }\end{array}$ & $\begin{array}{c}4.14 \\
(1.96)\end{array}$ & $\begin{array}{c}3.84 \\
(1.98)\end{array}$ & $\begin{array}{c}3.67 \\
(1.88)\end{array}$ & $\begin{array}{c}3.57 \\
(2.12)\end{array}$ & $\begin{array}{c}3.25 \\
(2.03)\end{array}$ & $9.466^{*}$ & 0.01 \\
\hline $\begin{array}{l}\text { Openness towards tourism } \\
\text { services that include } \\
\text { "driving" experience (test } \\
\text { driving) with AVs. }\end{array}$ & $\begin{array}{c}5.04 \\
(1.75)\end{array}$ & $\begin{array}{c}4.98 \\
(1.82)\end{array}$ & $\begin{array}{c}4.79 \\
(1.68)\end{array}$ & $\begin{array}{c}4.74 \\
(1.82)\end{array}$ & $\begin{array}{c}3.91 \\
(1.91)\end{array}$ & $19.531 * *$ & 0.03 \\
\hline
\end{tabular}

Note: ***: $p<0.001 ; * *: p<0.01 ; *: p<0.05$

Source: Authors' own editing based on empirical research. 
Based on Kruskall-Wallis-test, significant correlations between travel frequency and the attitude towards AV-based tourism services have been revealed (Table 4). Among those who travel more frequently for tourism purposes, the openness to use AVs is significantly higher. The effect size based on $\mathrm{Eta}^{2}$ is low (below 0.06) in all cases.

\section{Big-Five personality traits and tourism preferences}

Respondents were classified into the personality types based on their self-assessment. The selfassessment was based on answering standard questions ${ }^{7}$ suggested by the Big Five Personality Test. Based on the results, respondents of "Extraversion" category typically stay more than 3 nights in the destination visited. No significant differences by gender compared to the total sample have been detected. By age, the 18-29 age group is found in higher proportion in this category (40\%). A significantly higher proportion of subjects belong to this category who are interested in urban and cultural tourism.

The segment of "Agreeableness" has a higher share of longer trips (7-8 days), during which the demand for VFR tourism and active tourism products dominates. No significant difference by gender is observed compared to the overall sample. The proportion of age group 30-39 is slightly higher here (42\%) than in the total sample.

The group of "Conscientiousness" is also made up of subjects who prefer shorter trips of 13 nights. By gender, men are in a higher proportion in this category. By age, no significant difference has been found. Among respondents of the category "Neuroticism", trips of 3-4 days are the most common. In addition to VFR tourism, MICE tourism is also a popular travel motivation among them. No significant differences have been revealed by age and gender.

The highest proportion of subjects belonging to the "Openness to Experiences" prefer long trips (7-8 days). Female respondents make up a larger proportion of this group (66.6\%). Among them, urban tourism, active tourism and visiting festivals are the most popular reasons for travelling.

Correlations between personality traits and attitude towards AV use for tourism purposes have been found (Table 5). Based on the test statistics, the attitudes of subjects within the category of "Extraversion" (A) are significantly more positive towards each alternative of tourism related AV usage. Results revealed that there is also a significant correlation between "Neuroticism" (D) personality and lower attractivity of tourism related AV services. Among respondents of "Extraversion" (A) and "Agreeableness" (B) categories, the idea of experience

\footnotetext{
${ }^{7}$ https://bigfive-test.com/
} 
driving is the most attractive, whereas the same service is the least attractive among subjects who belong to the "Neuroticism" (D) category. It can be concluded that respondents of the "Conscientiousness" (C) category seems to be less open to using AVs for tourism purposes. Among tourists of "Openness to Experiences" category (E), the evaluation of each tourismbased alternative is significantly positive. In this category, the most attractive services are also the idea of test driving as well as sightseeing with AVs.

Table 5. Correlations between the attitude towards AV use for tourism purposes and personality traits based on Big Five theory

\begin{tabular}{|c|c|c|c|c|c|}
\hline Item & A & B & $\mathrm{C}$ & $\mathrm{D}$ & E \\
\hline $\begin{array}{l}\text { Openness to use AVs to pay } \\
\text { more attention to the } \\
\text { surroundings. }\end{array}$ & $0.090^{*}$ & & & & $0.258^{* * *}$ \\
\hline $\begin{array}{l}\text { Openness to carry out } \\
\text { additional activities (reading, } \\
\text { entertainment, etc.) during } \\
\text { traveling by AVs. }\end{array}$ & $0.094 *$ & $0.090^{*}$ & $-0.095^{*}$ & $-0.107^{*}$ & $0.241 * * *$ \\
\hline $\begin{array}{l}\text { Openness to use AVs in special } \\
\text { traffic situations (e.g., right- or } \\
\text { left-hand traffic). }\end{array}$ & & & & & $0.191 * * *$ \\
\hline $\begin{array}{l}\text { Intention to use AVs while } \\
\text { sightseeing. }\end{array}$ & & & & & $0.273^{* * *}$ \\
\hline $\begin{array}{l}\text { Willingness to visit more } \\
\text { distant destinations when using } \\
\text { AVs. }\end{array}$ & & & & $-0.098^{*}$ & $0.208^{* * *}$ \\
\hline $\begin{array}{l}\text { Openness to AV use in } \\
\text { unfamiliar environments. }\end{array}$ & $0.083^{*}$ & & & & $0.213^{* * *}$ \\
\hline $\begin{array}{l}\text { Openness to do sightseeing } \\
\text { conducted by an AI-based tour } \\
\text { guide (AutoTour). }\end{array}$ & $0.198 * * *$ & & & & $0.243^{* * *}$ \\
\hline $\begin{array}{l}\text { Openness to use AVs that are } \\
\text { suitable to conduct meetings. }\end{array}$ & $0.137 * * *$ & & & $-0.089^{*}$ & $0.232 * * *$ \\
\hline $\begin{array}{l}\text { Openness to use AVs which } \\
\text { have an interior design for } \\
\text { sleeping. }\end{array}$ & $0.133 * * *$ & & & & $0.188^{* * *}$ \\
\hline $\begin{array}{l}\text { Openness towards tourism } \\
\text { services that include "driving" } \\
\text { experience (test driving) with } \\
\text { AVs. }\end{array}$ & $0.228 * * *$ & $-0.120^{* *}$ & & $-0.118 * *$ & $0.279^{* * *}$ \\
\hline
\end{tabular}

Notes: ***: $p<0.001$; **: $p<0.01$; *: $p<0.05$. Abbreviation to the table: A-Extraversion, B - Agreeableness, $C$-Conscientiousness, D-Neuroticism, E-Openness to Experiences

Source: Authors' own editing based on empirical research. 


\section{DISCUSSION AND CONCLUSION}

This research aimed to explore the potential impacts of SAE Level 4-5 autonomous vehicles in the field of tourism. As a result of the literature review, we have created three categories (handover of driving tasks, increasing accessibility of destinations, new (possible) applications of $A V s$ for tourism purposes) that synthesize the potential tourism alterations resulting from the use of AVs. Empirical research has revealed the attitudes of 671 respondents towards AVs for tourism purposes.

Based on the results and in relation to the research questions (RQs), the following conclusions have been drawn:

RQ1: How do tourists relate to the use of $A V s$ at the level of full automation?

Based on respondents' attitudes towards services, there is a generally positive (all mean values above 4) attitude towards the analysed applications of AVs in tourism.

RQ2: Which of the AV-based tourism services identified in the literature are attractive among tourists?

Based on the evaluations, the openness to use AVs for sightseeing and AI-based guided tours (AutoTour service) is particularly noteworthy. Tourists would also be open to use AVs while staying at the destination (e.g., for sightseeing). Subjects see an opportunity to use AVs to better observe the environment and to immerse themselves in the tourist experience instead of driving.

RQ3: What personality types are open to AV-based tourism services?

Higher openness can be detected among the 18-29 age group, who are taking longer trips (3-7 nights), and in the "Extraversion" and "Openness to Experiences" segment. This segment of tourists especially prefers urban and cultural tourism. It should be noted that the results show lower openness among subjects with other personality types (e.g., "Neuroticism").

The main added value of our research is that we have explored the potential impacts of AVs on tourism, on which very few empirical studies and international publications have been done before. In addition to the demographic data, we also specified the attitudes of the respondents based on different personality types, which is also a unique approach in the social studies of $\mathrm{AVs}$ and can be useful for a better market segmentation in the tourism sector. Although our empirical research is not based on a representative sample, it proposes relevant inputs for further research on tourism development, as a significant proportion of respondents regularly participate in tourism trips and mainly organize their trips individually, thus we have explored the view of an important consumer segment. 
Miskolczi, M., Kökény, L., Ásványi, K., Jászberényi, M., Gyulavári, T., Syahrivar, J.

The attitude analysis concerning AVs provides a basis for further empirical research in social sciences (e.g., modeling the technology acceptance of AVs in tourism, more detailed elaboration of AV-based tourism service elements) and help to prepare for the technology revolution for practitioners in tourism.

\section{Acknowledgement}

Project no. NKFIH-869-10/2019 has been implemented with support provided by the National Research, Development, and Innovation Fund of Hungary, financed under the Tématerületi Kiválósági Programme Funding Scheme.

\section{REFERENCES}

Anderson, J. M., Kalra, N., Stanley, K. D., Sorensen, P., Samaras, C., \& Oluwatola, O. (2014). Autonomous Vehicle Technology - A Guide for Policymakers. Santa Monica, Calif.: RAND Corporation, RR-443-1-RC.

Arbib, J., \& Seba, T. (2017). Rethinking Transportation 2020-2030. RethinkX, May, 143, 144.

Ásványi, K., Miskolczi, M., \& Jászberényi, M. (2020). Az önvezető járművek fogyasztói szokásokra és turizmusra gyakorolt hatása. Turisztikai és Vidékfejlesztési Tanulmányok. $5(1), 4-16$.

Bagloee, S. A., Tavana, M., Asadi, M., \& Oliver, T. (2016). Autonomous vehicles: challenges, opportunities, and future implications for transportation policies. Journal of modern transportation, 24(4), 284-303.

Bainbridge, A. (2018). Autonomous vehicles \& auto-tours. The Spontaneous Travel Company. Retrieved from: http://www.destinationcto.com/docs/AutoTour.pdf

Becker, F., \& Axhausen, K. W. (2017). Literature review on surveys investigating the acceptance of automated vehicles. Transportation, 44(6), 1293-1306.

Bissell, D., Birtchnell, T., Elliott, A., \& Hsu, E. L. (2020). Autonomous automobilities: The social impacts of driverless vehicles. Current Sociology, 68(1), 116-134.

Clements, L. M., \& Kockelman, K. M. (2017). Economic effects of automated vehicles. Transportation Research Record, 2606(1), 106-114.

Cobb-Clark, D. A., \& Schurer, S. (2012). The stability of big-five personality traits. Economics Letters, 115(1), 11-15.

Cohen, S. A., \& Hopkins, D. (2019). Autonomous vehicles and the future of urban tourism. Annals of Tourism Research, 74, 33-42.

Csiszár C., \& Földes, D. (2017). Autonóm járműveket is alkalmazó városi személyközlekedési rendszer modellje. Közlekedéstudományi Konferencia. Győr, Magyarország.

Currie, G. (2018). Lies, damned lies, AVs, shared mobility, and urban transit futures. Journal of Public Transportation, 21(1), 3.

De Raad, B. (2000). The big five personality factors: the psycholexical approach to personality. Hogrefe \& Huber Publishers.

De Sio, F. S. (2017). Killing by autonomous vehicles and the legal doctrine of necessity. Ethical Theory and Moral Practice, 20(2), 411-429.

Du, H., Zhu, G., \& Zheng, J. (2021). Why travelers trust and accept self-driving cars: an empirical study. Travel behaviour and Society, 22, 1-9. 
Fagnant, D. J., \& Kockelman, K. (2015). Preparing a nation for autonomous vehicles: opportunities, barriers, and policy recommendations. Transportation Research Part A: Policy and Practice, 77, 167-181.

Freudendal-Pedersen, M., Kesselring, S., \& Servou, E. (2019). What is smart for the future city? Mobilities and automation. Sustainability, 11(1), 221.

Gardner, B., \& Abraham, C. (2007). What drives car use? A grounded theory analysis of commuters' reasons for driving. Transportation Research Part F: Traffic Psychology and Behaviour, 10(3), 187-200.

Glancy, D. J. (2015). Autonomous and automated and connected cars-oh my: first generation autonomous cars in the legal ecosystem. Minn. JL Sci. \& Tech., 16, 619.

Gosling, S. D., Rentfrow, P. J., \& Swann, W. B. (2003). A very brief measure of the Big-Five personality domains. Journal of Research in Personality, 37, 504-528. https://doi.org/10.1016/S0092-6566(03)00046-1

Hondanews.com (2021). Honda launches next generation Honda SENSING Elite safety system with Level 3 automated driving features in Japan. Retrieved from https://hondanews.com/en-US/honda-corporate/releases/releasee86048ba0d6e80b260e72d443f0e4d47-honda-launches-next-generation-hondasensing-elite-safety-system-with-level-3-automated-driving-features-in-japan

IFMO (2016). Autonomous driving. The impact of vehicle automation on mobility behaviour. Institute of Mobility Research.

Jászberényi, M., Munkácsy, A. (2018). Közlekedés, mobilitás, turizmus. Budapest: Akadémiai Kiadó.

Kim, K. H., Yook, D. H., Ko, Y. S., \& Kim, D. H. (2015). An analysis of expected effects of the autonomous vehicles on transport and land use in Korea. New York University: New York, NY, USA.

Koul, S., \& Eydgahi, A. (2018). Utilizing technology acceptance model (TAM) for driverless car technology adoption. Journal of technology management \& innovation, 13(4), 3746.

Komarraju, M., Karau, S. J., Schmeck, R. R., \& Avdic, A. (2011). The Big Five personality traits, learning styles, and academic achievement. Personality and individual differences, 51(4), 472-477.

Kyriakidis, M., Happee, R., \& de Winter, J. C. F. (2015). Public opinion on automated driving: Results of an international questionnaire among 5000 respondents. Transportation Research, Part F. 32, 127-140.

Lagadic, M., Verloes, A., \& Louvet, N. (2019). Can carsharing services be profitable? A critical review of established and developing business models. Transport Policy, 77(C), 68-78.

Liljamo, T., Liimatainen, H., \& Pöllänen, M. (2018). Attitudes and concerns on automated vehicles. Transportation research part F: traffic psychology and behaviour, 59, 24-44.

Madigan, R., Louw, T., Wilbrink, M., Schieben, A., \& Merat, N. (2017). What influences the decision to use automated public transport? Using UTAUT to understand public acceptance of automated road transport systems. Transportation research part F: traffic psychology and behaviour, 50, 55-64.

Marletto, G. (2019). Who will drive the transition to self-driving? A socio-technical analysis of the future impact of automated vehicles. Technological Forecasting and Social Change, 139, 221-234.

Menezes, E., Maia, A. G., \& de Carvalho, C. S. (2017). Effectiveness of low-carbon development strategies: Evaluation of policy scenarios for the urban transport sector in a Brazilian megacity. Technological Forecasting and Social Change, 114, 226-241. 
Miskolczi, M., Ásványi, K., Jászberényi, M., \& Kökény, L. (2021). Hogyan döntsön a mesterséges intelligencia? - Az önvezető autók morális dilemmái. Magyar Tudomány, 182(3), 342-352.

NHTSA.com (2021). National Highway Traffic Safety Administration. Retrieved from https://www.nhtsa.gov/

Nielsen, T. A. S., \& Haustein, S. (2018). On sceptics and enthusiasts: What are the expectations towards self-driving cars?. Transport policy, 66, 49-55.

Nikitas, A., Kougias, I., Alyavina, E., \& Njoya Tchouamou, E. (2017). How can autonomous and connected vehicles, electromobility, BRT, hyperloop, shared use mobility and mobility-as-a-service shape transport futures for the context of smart cities?. Urban Science, 1(4), 36.

Payre, W., Cestac, J., \& Delhomme, P. (2014). Intention to use a fully automated car: Attitudes and a priori acceptability. Transportation research part F: traffic psychology and behaviour, 27, 252-263.

Pitcher, P. (2011). Hit the deck: impacts of autonomous vehicle technology on parking and commercial real estate. B.S. Urban Planning.

Platt, M. (2017). Drivers cautious but curious over automated cars: First Canadian study shows. Calgary: University of Calgary.

Prisecaru, P. (2016). Challenges of the fourth industrial revolution. Knowledge Horizons. Economics, 8(1), 57-62.

PWC (2018). Five trends transforming the Automotive Industry. Retrieved from https://www.pwc.com/hu/hu/kiadvanyok/assets/pdf/five_trends_transforming_the_aut omotive industry.pdf

Run, R. S., \& Xiao, Z. Y. (2018). Indoor autonomous vehicle navigation - a feasibility study based on infrared technology. Applied System Innovation, 1(1), 4.

SAE.org (2021). SAE International Releases Updated Visual Chart for Its "Levels of Driving Automation” Standard for Self-Driving Vehicles. Retrieved from https://www.sae.org/ news/press-room/2018/12/sae-international-releases-updated-visual-chart-for-its$\% \mathrm{E} 2 \% 80 \% 9$ Clevels-of-driving-automation $\% \mathrm{E} 2 \% 80 \% 9 \mathrm{D}$-standard-for-self-drivingvehicles

Schipper, F., Emanuel, M., \& Oldenziel, R. (2020). Sustainable Urban Mobility in the Present, Past, and Future. Technology and culture, 61(1), 307-317.

Simplypsychology.org (2021). Big Five Personality Traits. Retrieved from: https://www.simplypsychology.org/big-five-personality.html

Syahrivar, J., Gyulavári, T., Jászberényi, M., Ásványi, K., Kökény, L., \& Chairy, C. (2021). Surrendering personal control to automation: Appalling or appealing?.Transportation Research Part F: Traffic Psychology and Behaviour, 80, 90-103.

Sivak, M., \& Schoettle, B. (2015). Influence of current nondrivers on the amount of travel and trip patterns with self-driving vehicles. Michigan: University of Michigan Transportation Research Institute.

Tokody, D., \& Mezei, I. J. (2017, September). Creating smart, sustainable and safe cities. In 2017 IEEE 15th International Symposium on Intelligent Systems and Informatics (SISY) (pp.141-146). IEEE.

Tomczak, M., Tomczak, E. (2014). The need to report effect size estimates revisited. An overview of some recommended measures of effect size. TRENDS in Sport Sciences 1, $19-25$.

Tromaras, A., Aggelakakis, A., Hoppe, M., Trachsel, T., \& Anoyrkati, E. (2018). Future technologies in the EU transport sector and beyond: an outlook of 2020-2035. In The 4th Conference on Sustainable Urban Mobility (pp. 722-729). Cham: Springer. 
Tussyadiah, I. P., Zach, F. J., \& Wang, J. (2017). Attitudes toward autonomous on demand mobility system: The case of self-driving taxi. In Information and communication technologies in tourism 2017 (pp. 755-766). Cham: Springer.

Urry, J. (2004). The 'System of Automobility'. Theory, Culture \& Society, 21(4-5), 25-39.

Xu, Z., Zhang, K., Min, H., Wang, Z., Zhao, X., \& Liu, P. (2018). What drives people to accept automated vehicles? Findings from a field experiment. Transportation research part $C$ : emerging technologies, 95, 320-334.

Zhao, J., Liang, B., \& Chen, Q. (2018). The key technology toward the self-driving car. International Journal of Intelligent Unmanned Systems. 68(1), 116-134

Zmud, J. P., \& Sener, I. N. (2017). Towards an understanding of the travel behavior impact of autonomous vehicles. Transportation research procedia, 25, 2500-2519. 